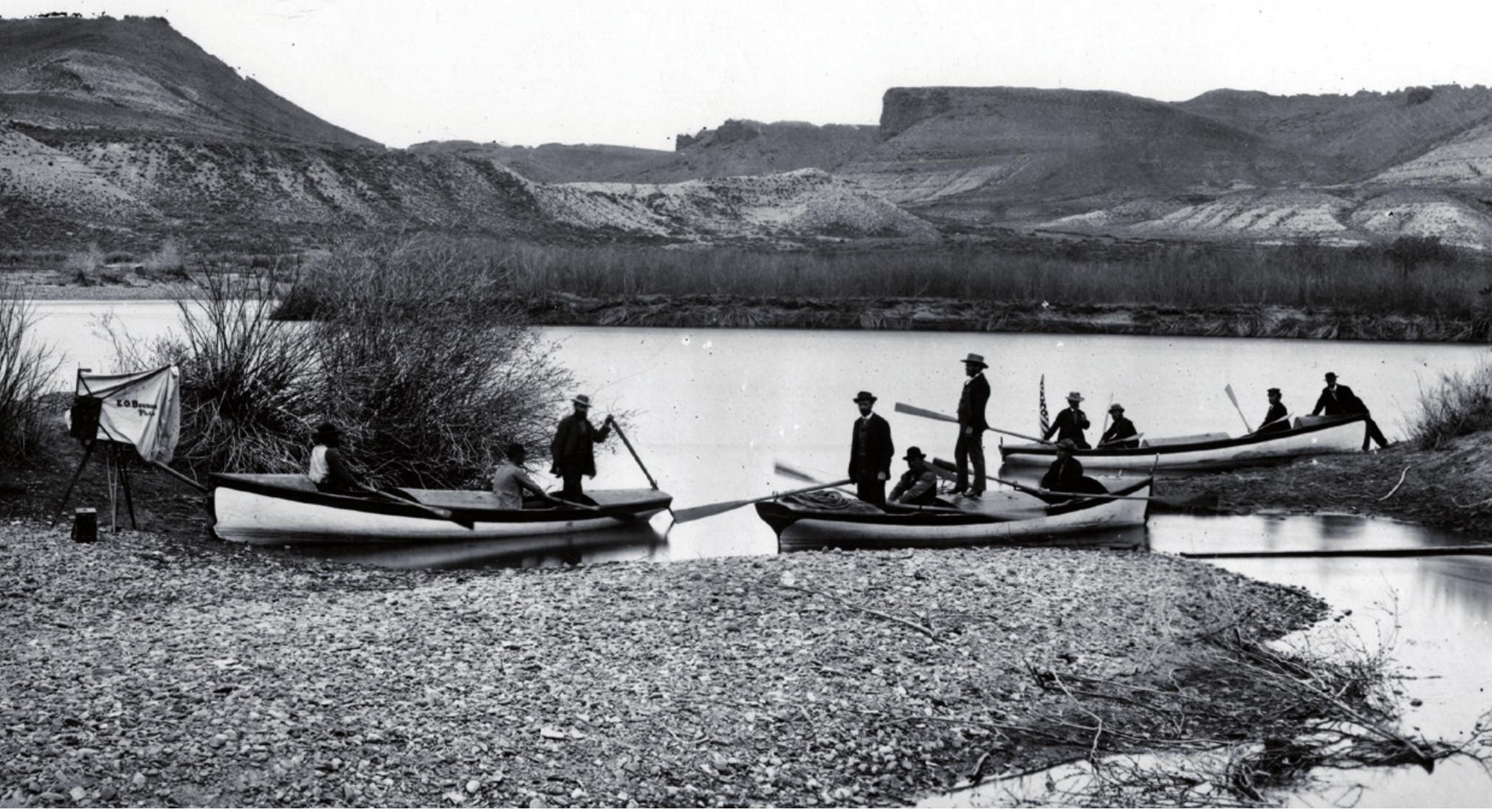

A party sets off from Wyoming on a scientific exploration of the western United States in May 1871.

\title{
Pushing the climate frontier
}

\section{The first large-scale environmental surveys, carried out on the US arid lands, hold scientific lessons for policy-making still relevant today, explains K. John Holmes.}

$\mathrm{W}$ hen nineteenth-century explorer William Gilpin travelled across the Great Plains, the expanse that covers much of the central and western United States, he marvelled at the "great pastoral region", the dry climate of which was "favorable to health, longevity, intellectual and physical development"1. Great cities could be built there, he imagined, taking advantage of the wealth of local resources - rivers, forests and even gold.

Geologist John Wesley Powell saw things differently. Moving from the humid east to the arid west would affect agricultural practices, occupations, social interactions and political customs, he contended ${ }^{2,3}$. Dry-land agriculture could not support a large population; any towns built in the west would need appropriate designs, irrigation and resource management. A controversy erupted.

The ensuing debates about how the arid lands should be settled hold lessons for us today on adapting to a changing climate. At their heart was a development plan for the region that Powell published in 1878 (ref. 2). It called for detailed scientific and engineering surveys, and analysis to inform land-use plans and laws. Although it addressed a spatial change in conditions caused by westward population expansion, Powell's coupling of physical and human dimensions was a forerunner to the assessment approach used today by the Intergovernmental Panel on Climate Change (IPCC).

Powell's plan was never implemented in its entirety, but it began an era in which large-scale environmental and naturalresources assessments became central to the policy process in the United States ${ }^{4}$. Stalled by misinformation, political controversy and recessions, legislation for allocating resources in the arid lands took decades to enact. Then, as now, the assessments and their validity became part of the debate. Eventually, extreme weather, including long

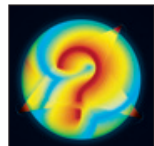

\section{OUTLOOK FOR EARTH}

A Nature special issue on the IPCC nature.com/ipcc2013 droughts, pushed policy-makers to act.

From New Mexico and the Dakotas to California's Sierra Nevada mountains, the arid lands of the United States - dubbed the Great American Desert in the accounts of other early nineteenth-century explorers such as Zebulon Pike - receive less than 50 centimetres of rainfall a year. With boundless land but limited water resources, the region's climate varies from desert to semi-arid.

\section{POWELL'S PLAN}

In his 1878 plan, Powell called for the coordinated development of water, land, forestry and mineral resources. He also proposed legislative and social initiatives for implementing it. Rather than selling off rectangular plots of public land, as was usual at the time, he argued that lands should first be classified for uses such as irrigation, pasture, forestry or mining before being released for sale to settlers. Natural resources should be managed cooperatively at local and river-basin levels.

Maps and analyses of topography, geology and climate would be needed for the land 
classifications. Determining how much land to set aside for irrigation, for example, would require hydrologic calculations and engineering designs, as well as surveys of potential reservoir sites and supporting infrastructure plans. Financial feasibility would also need to be demonstrated for different locations.

Some of Powell's proposals were innovative - in particular his suggestion to tie together land and water rights. By grouping together land parcels, every farm could own its irrigated land, and communities could manage large tracts of unfenced pastureland. He believed that social institutions, such as schools and churches, and infrastructure, including roads and bridges, would spring up as a result.

Powell saw watersheds as the natural boundaries for resource management. Defining areas in which people's interests were interlinked and that were large enough to pay for irrigation projects, he believed that such great "watershed commonwealths" would oversee the development of resources within a drainage basin ${ }^{5}$.

In 1881, Powell was appointed director of the US Geological Survey (USGS), tasked with surveying and classifying the lands of the west. He initiated a range of mapping and monitoring programmes, including streamflow, rainfall and preliminary reservoir surveys, culminating in a complete topographic map of the United States.

Mild weather conditions beginning after the conclusion of the American Civil War in 1865 , and continuing through the early 1880 s, allowed steady migration to the arid lands. States such as Nebraska, Kansas and Colorado doubled or tripled in population. But drought between the late 1880 s and early 1890 s, coincid-

\section{"Motivation to act might come only from rare catastrophic events such as droughts."}

ing with poor national economic conditions, caused starvation, bankruptcy and social unrest $^{6}$. Some 300,000 people migrated out of the arid region. The relative population drop of $50-75 \%$ was worse than for any subsequent drought ${ }^{6}$.

A national debate about the future of the region began, with Powell's plan at the centre. US Congress enacted legislation in 1888 that halted the release of public lands to settlers for two years while the USGS characterized the region. Powell estimated that it would take 10 years and US\$6 million to map the approximately 2.6 million square kilometres of arid lands; at the time, the USGS annual budget was just $\$ 700,000$. However, his first task was to recruit and train staff.

When Powell sought extra time to perform the full land and resource assessment, Congress and the public turned against him, and his plan fell from favour. The policy

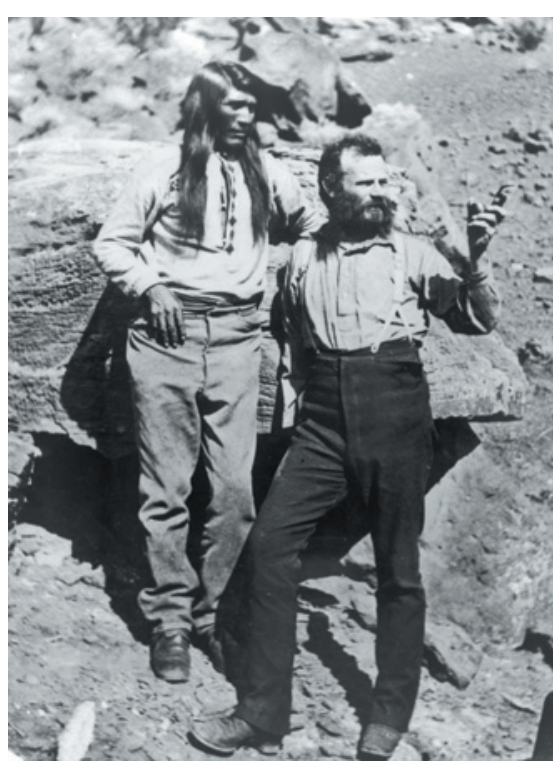

Geologist John Wesley Powell (right) with his Paiute guide Tau-gu in Utah in 1873.

was reversed and the release of public lands recommenced in 1890 . The USGS budget was frozen and its hydrographers discharged. With Powell's departure from the agency in 1894, attempts to develop large-scale resource management in the region effectively ended ${ }^{7}$.

But there was a continuing clamour for a national policy to address the climate of the arid lands, especially through irrigation. In 1896 , Congress commissioned a report ${ }^{8}$ to identify the best body to build and operate irrigation systems; basin-based organizations were though to be too small to raise enough capital or to operate across states. The federal government was nominated, and the Reclamation Act of 1902 established a dominant federal role in reservoir construction.

\section{POWELL'S LEGACY}

The trajectory of Powell's plan holds lessons for the climate-change debate today. The parallels are striking — the arid-lands debate extended over a long period and resulted in scientific controversy and heated political discussions.

Powell established that data, analyses and proposals must be the basis for policy decisions. His assessment provided the first detailed understanding of the climate in the arid lands, as well as "definite information upon which the committees of Congress and the individuals interested could base their statements or conclusions" broad scientific legacy, including tools such as a national topographic map and climatemonitoring systems that are still in use. Likewise, the IPCC reports will continue to provide value in decades to come through their monitoring, analyses and policy proposals.

The public response to Powell's plan and to the need to address the climate of the arid lands is telling. Opinion swung back and forth over many decades as a multitude of factors intervened, including misinformation campaigns and external events such as economic recessions and unusual weather conditions. In a similar way, the climatechange debate today ebbs and flows.

The collapse of Powell's watershed-based strategy demonstrates the importance of choosing appropriate institutions and economic policies. His call for a class of selffinanced regional-management entities, taking responsibility for resource management away from existing federal and state bodies, failed because it was not feasible economically or politically. Similarly, management scale and political realities must be considered when implementing various climate-change-mitigation strategies.

For complex issues such as climate change, history reminds us that the first comprehensive policy adopted will not be the last. Policies evolve. The addressing of irrigation needs through the Reclamation Act, although itself the culmination of a lengthy debate, was bolstered three decades later by soil-conservation efforts in response to the extreme Dust Bowl conditions of the 1930s.

Sadly, in the end, the motivation to act might come only from rare catastrophic events such as droughts; human cost offers a sharp impetus for politicians. As a US senator noted in a 1935 debate, a Great Plains dust storm that travelled more than 1,600 kilometres to reach the country's capital was "the most tragic, the most impressive lobbyist" in those earlier deliberations over climatic disaster ${ }^{10}$.

K. John Holmes is associate director of the Board on Energy and Environmental Systems at the US National Research Council in Washington DC. e-mail:jholmes@nas.edu

1. Gilpin, W. The Central Gold Region (Sower, Barnes and Company, 1860).

2. Powell, J. W. Report on the Lands of the Arid Region of the United States (US Department of the Interior, 1878).

3. USGS. Twelfth Annual Report of the United States Geological Survey to the Secretary of the Interior, 1890-91, Part II-Irrigation (Government Printing Office, 1891)

4. Holmes, K. J. \& Wolman, M. W. Environ. Mgmt 27, 177-193 (2001).

5. Powell, J. W. The Century Magazine 40, 111-116 (1890).

6. Warrick, R. A. Climatic Constraints and Human Activities (eds Ausubel, J. \& Biswas, A. K.) (Pergamon, 1980).

7. Van Hise, C. R. The Conservation of Natural Resources in the United States (Macmillan, 1910).

8. United States Army Corps of Engineers. Preliminary Examination of Reservoir Sites in Wyoming and Colorado (US Congress, 1897)

9. USGS. Twenty-third Annual Report of the Director of the United States Geological Survey to the Secretary of the Interior 1901-2 (Government Printing Office, 1902).

10.Statement of Senator Thomas Gore (Oklahoma). Congressional Record 79, 6013 (Government Printing Office, 1935). 